\title{
Wykorzystanie metod optycznych do lokalizacji uszkodzeń zmęczeniowych
}

\section{Utilization of optic methods for fatigue failure location}

\section{Streszczenie}

Monitorowanie zjawisk związanych ze zmęczeniem materiałów jako procesu inicjowanego lokalnie wymaga całopolowych obserwacji deformacji zachodzących pod wpływem obciążeń zmęczeniowych. Metoda elektronicznej interferometrii plamkowej (ESPI) pozwala z dużą precyzją (przy zachowaniu stabilności układu pomiarowego) określić rozkład odkształceń na powierzchni próbki i tym samym wskazać miejsca koncentracji naprężeń wywołanych karbem (strukturalnym, geometrycznym). Możliwa jest także ocena rozwoju tych deformacji w kolejnych cyklach zmęczenia aż do utworzenia pęknięcia i dekohezji próbki. Bieżący pomiar odkształceń w strefie ich lokalizacji pozwala na ilościową ocenę dynamiki rozwoju uszkodzenia zmęczeniowego w badanym materiale.

\section{Wyniki eksperymentu}

Wykorzystanie metody ESPI, dającej polowy obraz rozkładu deformacji, do badania próbek z porowatego siluminu umożliwia zlokalizowanie miejsca inicjacji uszkodzenia pod wpływem obciążeń cyklicznych oraz monitorowanie rozwoju tego uszkodzenia w badanym materiale [1]. Próbki z porowatego siluminu o minimalnym przekroju $18 \times 4 \mathrm{~mm}$ poddano rozciągającym naprężeniom cyklicznym o wartości $100 \mathrm{MPa}$, co stanowiło $64 \%$ granicy plastyczności dla tego stopu. Obrazy rozkładu deformacji pod wpływem obciążeń rejestrowano w 1, 2, 3, 5, 1000, 25 000, 100000 , 200000 i 300000 cykli, z wykorzystaniem statycznego układu obciążającego z ręczną pompę hydrauliczną. Zapis obrazów przemieszczeń w czasie realizacji

Prof. dr hab. inż. Lech Dietrich, mgr inż. Paweł Grzywna, dr inż. Dominik Kukla - Instytut Podstawowych Problemów Techniki PAN.

\begin{abstract}
Monitoring the phenomena related to the materials' fatigue as the process initiated locally requires the full-field observations of the displacement brought about by the fatigue strain. The Electronic Speckle Pattern Interferometry method enables to determine the distribution of displacement on the sample surface (retaining the stability of the measurement arrangement) and thus indicate the strain and also the stress concentration spots resulting from the defect (structural, geometrical one). It is also possible to assess the development of those distortions in consecutive fatigue cycles until the crack is formed and the sample decohesion takes place. The current measurement of displacements in their location zone enables to carry out a quantitative assessment of the fatigue failure development dynamics in the material evaluated.
\end{abstract}

obciążeń dynamicznych na maszynie hydraulicznej, na której wykonywane były testy zmęczeniowe, jest niemożliwy z uwagi na generowane drgania układu przewyższające dziesięciokrotnie dokładność pomiarową metody ESPI. Rejestracji przemieszczeń dokonywano dla narastającego obciążenia rozciągającego w wybranym cyklu według schematu pokazanego na rysunku 1 . Ze względu na wysokie wartości

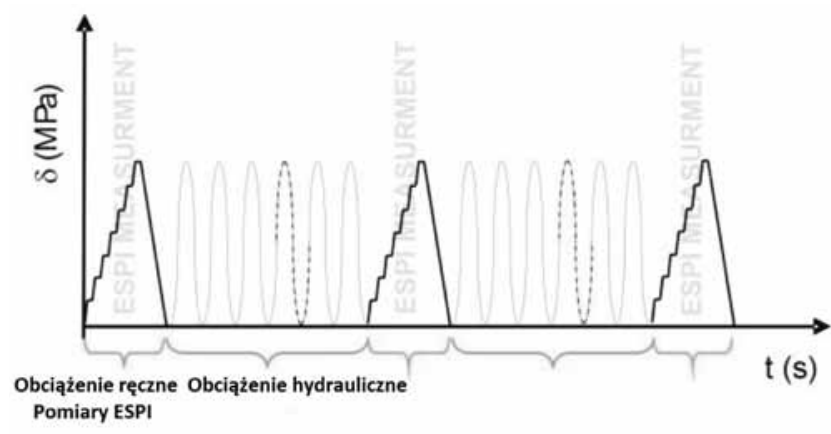

Rys. 1. Schemat obciążenia próbki w cyklach zmęczeniowych Fig. 1. Scheme of the sample load fatigue cycles 


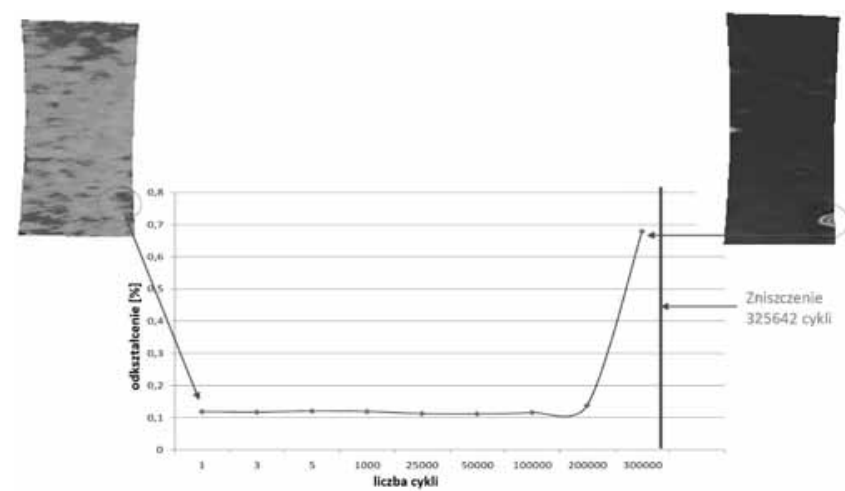

Rys. 2. Lokalizacja deformacji oraz jej rozwój w kolejnych cyklach obciążenia

Fig. 2. Deformation location and it propagation in the following load fatigue cycles

przemieszczeń w próbce pod wpływem naprężenia konieczne było wykonanie pomiarów w siedmiu krokach, począwszy od 1,2 kN aż do wartości 7,2 kN, która odpowiadała naprężeniu $100 \mathrm{MPa}$.

Obserwacje jednej z powierzchni próbki wykazały efekt lokalizacji przemieszczeń już w pierwszych cyklach obciążenia, co widoczne jest najlepiej na mapach odkształceń w kierunku działania siły osiowej - kierunku nazwanym $Y$ (rys. 2). Proces ten rozwijał się $w$ tym miejscu aż do pęknięcia próbki w 325642 cyklu. Na rysunku 3 pokazano obrazy odkształceń dla 1, 200000 oraz 300000 cykli. Dla wszystkich pomiarów w kierunku $Y$ wyznaczono rozkład odkształceń w kierunku prostopadłym do osi próbki, w miejscu lokalizacji deformacji. Na tej podstawie określono ilościowy przyrost odkształceń rejestrowanych w kolejnych sekwencjach obciążenia rozciągającego. Wynik obrazuje wykres na rysunku 2, gdzie pokazano zmianę wartości maksymalnego odkształcenia uzyskanego w kolejnych cyklach. Z obserwacji tych zmian wynika, że lokalny przyrost odkształceń powstały już w pierwszym cyklu obciążenia pozostaje niezmienny przez kolejne 200000 cykli, a następnie dynamika jego rozwoju gwałtownie wzrasta aż do pęknięcia przy 325642 cyklu. llościowe zmiany w wartościach odkształcenia uwidaczniają profile wykonane w miejscu jego lokalizacji od pierwszego cyklu obciążenia do 200000 cyklu (rys. 4).

We wszystkich zarejestrowanych cyklach zmęczenia najwyższe wartości odkształcenia zlokalizowane są przy prawej krawędzi próbki, gdzie zainicjowane zostało uszkodzenie. Profil 200000 cyklu

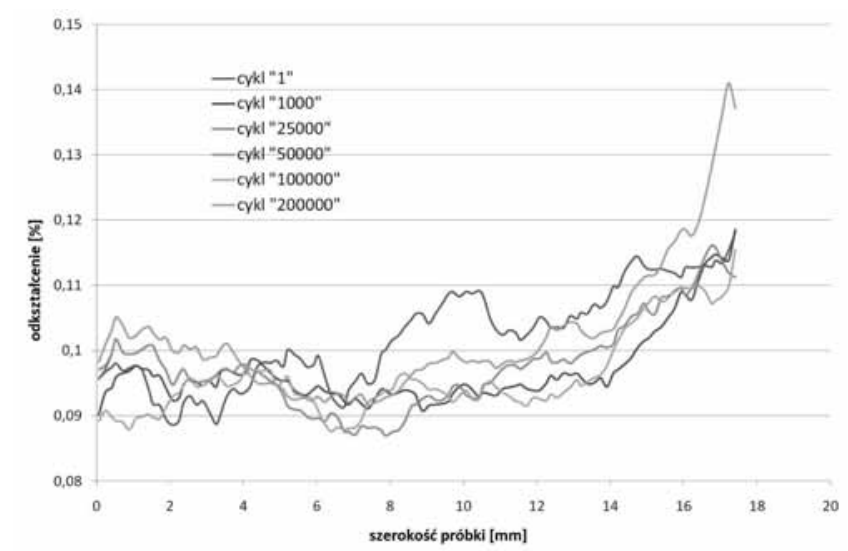

Rys. 4. Poprzeczne profile zmian odkształceń w przekroju o jego maksymalnych wartościach

Fig. 4. The lateral profiles of cross-sectional strain changes of maximum values

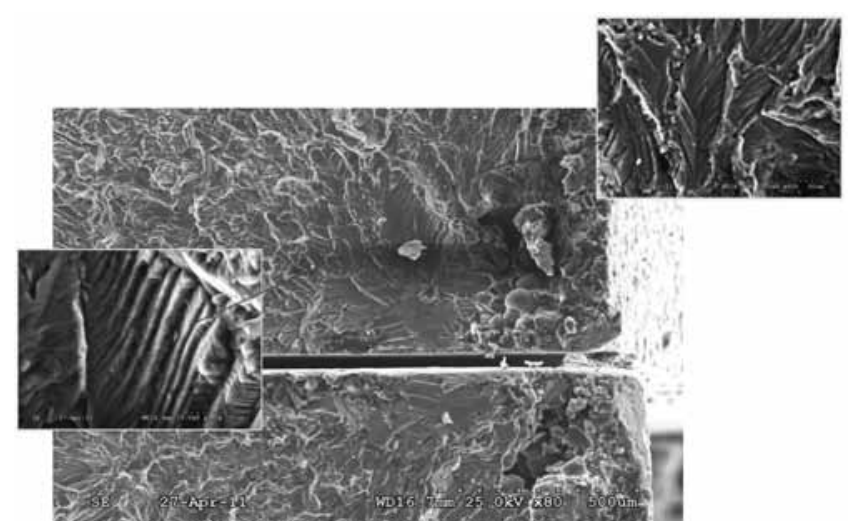

Rys. 5. Przełom próbki z widocznym na obu częściach porem oraz zbliżenie prążków zmęczeniowych w orzasze jego występowania Fig. 5. Fracture of the sample with void in both sides and the convergence of fatigue striations in the void surrounding area
1 cykl

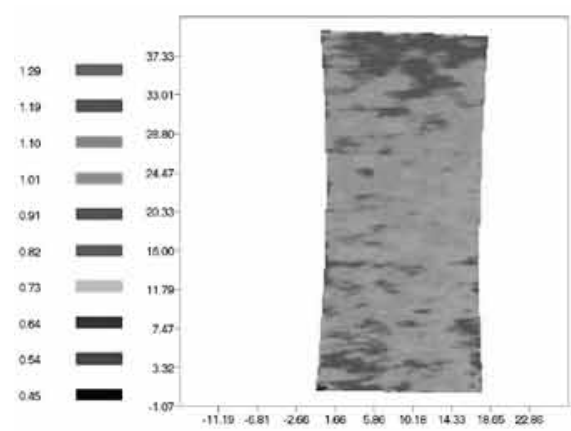

100000 cykli

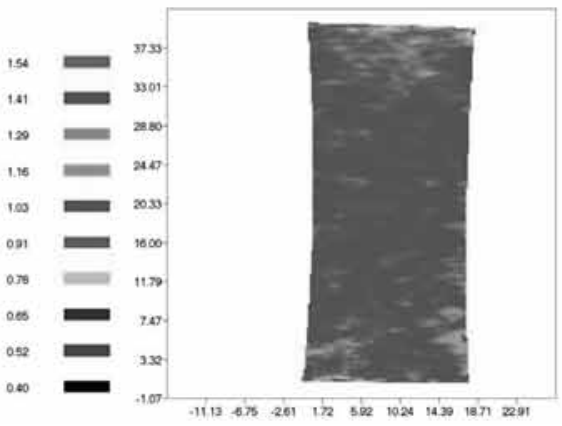

300000 cykli

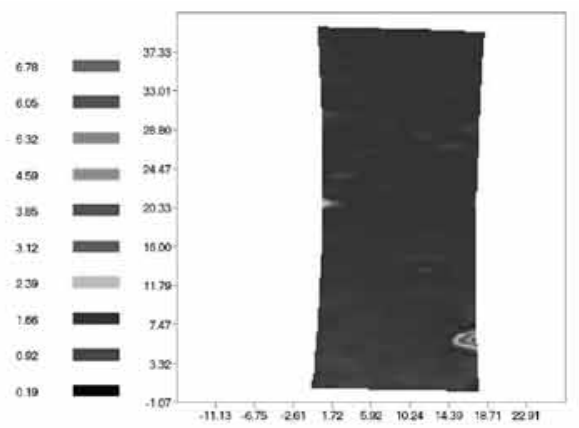

Rys. 3. Wyniki pomiarów - mapy odkształceń w kierunku $Y$ (wzdłuż osi działania siły). Wymiary próbki podane w mm, wartości odkształceń 0,001

Fig. 3. Measurement results - maps of strain in $Y$ direction (along force axis). Dimensions in $\mathrm{mm}$, strain values as 0.001 
wskazuje na zwiększenie dynamiki odkształceń w tym miejscu. Jak widać na mikroskopowych zdjęciach fraktograficznych, przyczyną takiego umiejscowienia odkształceń była koncentracja naprężeń na liczącym ponad $200 \mu \mathrm{m}$ porze (rys. 5). Na przełomie próbki zaobserwowano liczne pory o podobnej wielkości, jednak położenie przy obu krawędziach powierzchni bocznych próbki wpłynęło na inicjację procesu zniszczenia w tym właśnie miejscu (rys. 6). Fakt ten potwierdzają prążki zmęczeniowe, jakie można zaobser-
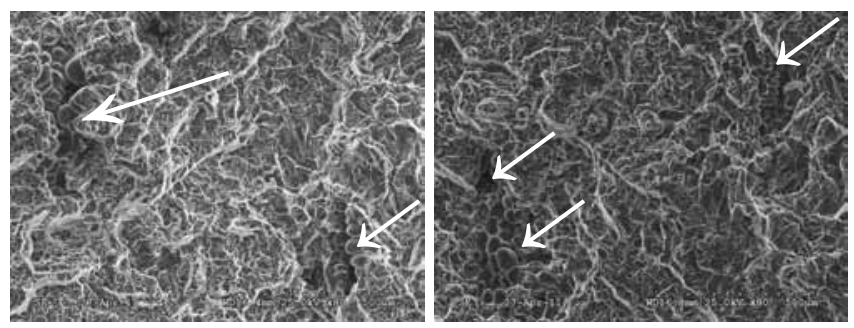

Rys. 6. Jedne z licznych porów na powierzchni przełomu Fig. 6. Example of voids in fracture face wować w różnych kierunkach wokół pustki (rys. 5).

\section{Wnioski}

Pomiar stopnia zmęczenia w materiałach jest możliwy za pomocą pomiaru parametru uszkodzenia opisanego w [2], nie umożliwia on jednak lokalizacji uszkodzeń zmęczeniowych. Lokalizacja uszkodzeń zmęczeniowych jest możliwa za pomocą polowych metod badań deformacji powierzchni lub metod defektoskopowych. Proces zmęczenia w materiale porowatym, takim jak badany stop odlewniczy

aluminium, wykazuje efekt lokalizacji odkształceń już w pierwszych cyklach obciążenia. Spowodowane jest to licznymi koncentratorami naprężeń w postaci pustek i porów. Efekt lokalizacji jest jednak możliwy do obserwacji tylko przy podpowierzchniowym położeniu pustek inicjujących proces zmęczenia oraz przy zastosowaniu polowych metod obserwacji, takich jak metoda ESPI lub DIC (Digital Image Correlation).

\section{Literatura}

[1] Dietrich L., Grzywna P., Kukla D.: Material damage prediction in cast aluminum alloy using elektronic speckle pattern interferometry, 27th Danubia Adria Symposium on Developments in Experimental Mechanics, September 2010, Wrocław, Poland.
[2] Kukla D., Grzywna P.: Ocena rozwoju procesów zmęczeniowych związanych z lokalnymi odkształceniami na przykładzie stali P91 dla energetyki, Energetyka 8/2012, s. $405-410$.

\section{SpaWningligiun}

Redakcja Przegląd Spawalnictwa, ul. Świętokrzyska 14a, 00-050 Warszawa tel.: 2282725 42, fax: 22336 14 79; e-mail: pspaw@ps.pl, www.pspaw.ps.pl 